\title{
Morphology, mechanical strength and degradation of polụhuydroxyalkanoate scaffolds
}

\author{
Morfología, resistencia mecánica y degradación de plataformas de \\ polihidroxialcanoato
}

Morfologia, resistência mecânica e degradação de plataformas de polihidroxialcanoato

Fecha de recepción: 18 de noviembre de 2017

Fecha de aprobación: 17 de enero de 2018

Liliana María Arroyave-Muñoz*

Claudia Patricia Ossa-Orozco**

\section{Abstract}

Tissue engineering (TE) seeks to improve the unsatisfactory development of implants and medical procedures to solve bone and cartilage injuries. TE aims at regenerating tissues using cell growth platforms (scaffolds), which may consist of natural polymers such as polyhydroxyalkanoate (PHA). PHA is an innovative material useful in medical applications due to its degradation capability and bacterial origin that allows large-scale production and control final properties. In this research, we developed commercial PHA scaffolds using the lyophilization technique with a factorial experimental design. We used dichloromethane as PHA solvent, tergitol as surfactant, and liquid nitrogen $\left(\mathrm{N}_{2}\right)$ for the freezing process. We characterized the PHA by Fourier-transform infrared spectroscopy (FTIR) and thermogravimetric analysis (TGA); and the scaffolds by scanning electron microscopy (SEM) and mechanical compression and hydrolysis degradation tests. The characterization of the PHA indicated that the material is a mixture of PHA and polylactic acid (PLA). The results showed a suitable pore distribution for migration of chondrocytes through the scaffold, in addition to a behavior similar to that of the articular cartilage, although it presented lower mechanical strength. Also, the scaffolds displayed mass loss in a non-linear way related to the percentage of PHA present in the sample. In conclusion, PHA scaffolds have a potential use in tissue engineering for restoring articular cartilage.

Keywords: articular cartilage; polyhydroxyalkanoate; scaffolds; tissue engineering.

\section{Resumen}

Actualmente, el desarrollo de implantes o procedimientos médicos para resolver lesiones óseas o cartilaginosas no cumple satisfactoriamente con los requerimientos funcionales del tejido afectado; una solución alternativa es el uso de la ingeniería de tejidos (IT), que busca regenerar el tejido con plataformas de crecimiento celular fabricadas, por ejemplo, con polímeros naturales, como el polihidroxialcanoato (PHA), que permite la reconstrucción del tejido gracias a su capacidad de degradación, y cuyo origen bacteriano permite la producción a gran escala y el control de las propiedades finales. En este proyecto se desarrollaron scaffolds de PHA comercial, mediante la técnica de liofilización, con un diseño experimental factorial, utilizando diclorometano como solvente, Tergitol

* Universidad de Antioquia (Medellín-Antioquia, Colombia). liliana.arroyave@udea.edu.co

** Ph.D. Universidad de Antioquia (Medellín-Antioquia, Colombia). claudia.ossa@udea.edu.co. 
como surfactante y nitrógeno líquido $\left(\mathrm{N}_{2}\right)$ como congelante. El PHA se caracterizó con espectroscopia de infrarrojo (FTIR) y análisis termogravimétrico (TGA). Los scaffolds obtenidos se caracterizaron con microscopia electrónica de barrido (SEM), ensayos mecánicos de compresión y ensayos de degradación hidrolítica. Los análisis sobre el PHA indicaron que el material es una mezcla de dicho polímero y ácido poliláctico (PLA). Los scaffolds mostraron una distribución de poros adecuada para la migración de condrocitos a través de ellos y presentaron un comportamiento similar al cartílago articular, pero una menor resistencia mecánica; también se encontró que la pérdida de masa está relacionada con el porcentaje de PHA presente en la muestra de una forma no lineal. En conclusión, los scaffolds de PHA tienen un potencial uso en la ingeniería de tejidos para la restauración de cartílago articular.

Palabras clave: andamios; cartílago articular; ingeniería de tejidos; polihidroxialcanoato.

\section{Resumo}

Atualmente, o desenvolvimento de implantes ou procedimentos médicos para resolver lesões ósseas ou cartilaginosas não cumpre satisfatoriamente com os requerimentos funcionais do tecido afetado; uma solução alternativa é o uso da engenharia de tecidos (IT), que busca regenerar o tecido com plataformas de crescimento celular fabricadas, por exemplo, com polímeros naturais, como o polihidroxialcanoato (PHA), que permite a reconstrução do tecido graças a sua capacidade de degradação, e cuja origem bacteriana permite a produção a grande escala e o controle das propriedades finais. Neste projeto desenvolveram-se scaffolds de PHA comercial, mediante a técnica de liofilização, com um desenho experimental fatorial, utilizando diclorometano como solvente, Tergitol como surfactante e nitrogênio líquido $\left(\mathrm{N}_{2}\right)$ como congelante. O PHA caracterizou-se com espectroscopia de infravermelho (FTIR) e análise termogravimétrica (TGA). Os scaffolds obtidos caracterizaramse com microscopia eletrônica de varredura (SEM), ensaios mecânicos de compressão e ensaios de degradação hidrolítica. As análises sobre o PHA indicaram que o material é uma mistura deste polímero e ácido poliláctico (PLA). Os scaffolds mostraram uma distribuição de poros adequada para a migração de condrócitos através deles e apresentaram um comportamento similar à cartilagem articular, mas uma menor resistência mecânica; também se encontrou que a perda de massa está relacionada com a porcentagem de PHA presente na amostra de uma forma não lineal. Em conclusão, os scaffolds de PHA têm um potencial uso na engenharia de tecidos para a restauração de cartilagem articular.

Palavras chave: andaimes; cartilagem articular; engenharia de tecidos; polihidroxialcanoato.

\section{Para citar este artículo:}

L. M. Arroyave-Muñoz, and C. P. Ossa-Orozco, "Morphology, mechanical strength and degradation of polyhydroxyalkanoate scaffolds," Revista Facultad de Ingeniería, vol. 27 (48), pp. 61-70, May. 2018. 


\section{INTRODUCTION}

The last survey of the National Administrative Department of Statistics (DANE, 2005) showed that, in Colombia, 2,018,078 people have alterations in body function or structure. These conditions deteriorate people's quality of life and involve their social, labor and educational isolation [1]. In many cases, it is necessary to use implants to improve the functionality of the damaged structure; a clear example is the articular cartilage, an avascular tissue unable to self-regenerate [2].

Traditional alternatives to recover cartilage functionality, such as microfracture, generate scars through fibrocartilage that fail satisfying the mechanical, morphological or chemical stresses of native tissue [3]. Cartilage autografts and allografts have difficulties such as low availability, compatibility and morbidity induced in the patient, making these procedures impractical [3]. The prosthesis used to repair articular cartilage can eliminate pain and partially restore functionality, but its lifetime is short [3] since the materials used to manufacture it do not meet the mechanical requirements [4].

Due to the difficulties restoring cartilaginous tissue, as other tissues in the body, TE proposes the stimulation of tissue regeneration rather than the replacement thereof, making necessary to use cell growth platforms or scaffolds. These platforms provide an ideal environment for the cells to generate their own extracellular matrix; therefore, using materials with degradation capacity is important so they can be replaced by the cell's own extracellular matrix [5]. Consequently, platforms with polymeric biomaterials such as polyhydroxyalkanoates (PHA) have been developed in recent years, thanks to their biocompatibility, adjustable mechanical properties and capacity to degrade without leaving toxic residues [6].

In this study, we manufactured PHA scaffolds by varying the percentage of PHA to determine the optimal manufacturing protocol that balances the mechanical, morphological and chemical requirements of cartilaginous tissue.

\section{Materials And Methods}

\section{A. Materials}

The polyhydroxyalkanoate (PHA) was obtained from Goodfellow as a degradable polymer for extrusion composed of PHA. The polylactic acid (PLA) and some additives, and the dichloromethane (methylene chloride) were obtained from Químicos J.M. S.A., and the tergitol from AlfaQuímicos Ltda.

\section{B. Characterization of $\mathrm{PHA}$}

We used Fourier Transform Infrared Spectroscopy (FTIR) to identify the functional groups [7], using a PerkinElmer brand Spectrum One model, with a DTGS detector. We prepared the sample by manufacturing a $\mathrm{KBr}$ tablet with an approximate ratio of $100: 1 \mathrm{mg}(\mathrm{KBr} /$ sample), applying five tons of pressure. We analyzed the behavior of the polymer regarding temperature change through a thermogravimetric analysis (TGA) [8], with an initial sample size of $15.847 \mathrm{mg}$, in a TGA Q500 V20.13 Build 39 device and a temperature ramp of $25^{\circ} \mathrm{C}$ to $900{ }^{\circ} \mathrm{C}$, at a heating rate of $10^{\circ} \mathrm{C} / \mathrm{min}$ with a nitrogen atmosphere.

\section{Manufacturing of scaffolds}

To manufacture the scaffolds, we began by dissolving PHA in dichloromethane in percentages of $5 \%$, $7.5 \%$ and $10 \% \mathrm{wt} / \mathrm{v}$ (values obtained after previous experimentation), then, we added tergitol to ensure the emulsion of the solution with water. The amount of reagent corresponded to $7.8 \% \mathrm{w} / \mathrm{w}$ of the water and polymer used, mixing for $15 \mathrm{~min}$, then we added water in a volume corresponding to $75 \% \mathrm{w} / \mathrm{w}$ of the polymer and the dichloromethane; the water was added by dripping with continuous stirring for one hour. The water allows the melting temperature of the solution to increase, making sure that the whole system is closed to avoid the volatilization of dichloromethane. We poured the emulsion into cylindrical molds (12.7 $\mathrm{mm}$ in diameter and $25.4 \mathrm{~mm}$ in height) previously frozen, left the outer walls of the molds in contact with the nitrogen until total freezing, and then lyophilized them for $48 \mathrm{~h}$ in a Labconco 2.5 L lyophilizer. Before testing, we washed the samples to remove remnants of tergitol and dichloromethane with $100 \%$ ethanol for one hour, followed by $75 \%$ ethanol for half an hour, 
$50 \%$ ethanol for half an hour, $25 \%$ ethanol for half an hour, and finally distilled water for one hour.

\section{Characterization of the PHA scaffolds}

To evaluate the morphology of the scaffold porosity, we took micrographs with transversal and longitudinal slices with a scanning electron microscope (JEOL JSM$6490 \mathrm{LV}$ ) with $3 \mathrm{~nm}$ of resolution, at a magnification of $3,000 \mathrm{X}$. We performed compression tests in triplicate for each protocol with a speed of $5 \mathrm{~mm} / \mathrm{min}$ in a universal testing machine (Digimess TC500), following the ASTM D695-15 standard. Finally, we tested degradation in a simulated body fluid (SBF) at $7,14,21$ and 28 days with a temperature of $37^{\circ} \mathrm{C}$ in triplicate, according to the ASTM F1635 standard.

\section{Results AND Discussion}

\section{A. Characterization of the $\mathrm{PHA}$}

The band observed at $1729.12 \mathrm{~cm}^{-1}$ in the FTIR spectrum (Fig. 1) corresponds to a typical stretch of the amorphous carbonyl group $(\mathrm{C}=\mathrm{O})$ of PLA, which is also present in the PHA $[9,10]$ and whose amplitude may be due to the mixture of PLA-PHA by the stretching of carbonyl crystals of PHA, assuming that there is a molecular interaction [13]. Additionally, a band at $2853.44 \mathrm{~cm}^{-1}$ corresponds to the extension of - $\mathrm{CH}$ [9], characteristic of PLA, and another band at $3443.96 \mathrm{~cm}^{-1}$ corresponds to the $\mathrm{OH}$ group of the PHA [11]. There are several typical PLA bands present in the FTIR spectrum. The bands at $2991.37 \mathrm{~cm}^{-1}, 2926.72$ $\mathrm{cm}^{-1}$ and $2853.44 \mathrm{~cm}^{-1}$ correspond to the extension of $\mathrm{OH}$ characteristic of the PLA [9], and the band at 1182 $\mathrm{cm}^{-1}$ corresponds to the stretching of $\mathrm{C}-\mathrm{O}$ of the $\mathrm{CH}-\mathrm{O}$ group of the PLA that is overlapped. The $3443.96 \mathrm{~cm}^{-1}$ band, corresponding to the $\mathrm{OH}$ group, and the 1729.12 $\mathrm{cm}^{-1}$ band, corresponding to the carbonyl group, are typical of the PHA [11]. The bands at $1447.50 \mathrm{~cm}^{-1}$ and $1395.9 \mathrm{~cm}^{-1}$ correspond to the deformation of $\mathrm{CH}_{3}$ and the extension of C-O-C, respectively, both present in PHA and PLA [10]. Apparently, the 1045.49 $\mathrm{cm}^{-1}$ band in the FTIR does not correspond to any component of the PHA nor the PLA, however, two peaks seem to overlap close to $1089 \mathrm{~cm}^{-1}$ and 1057 $\mathrm{cm}^{-1}$, corresponding to a helical structure belonging to the PHA [10].

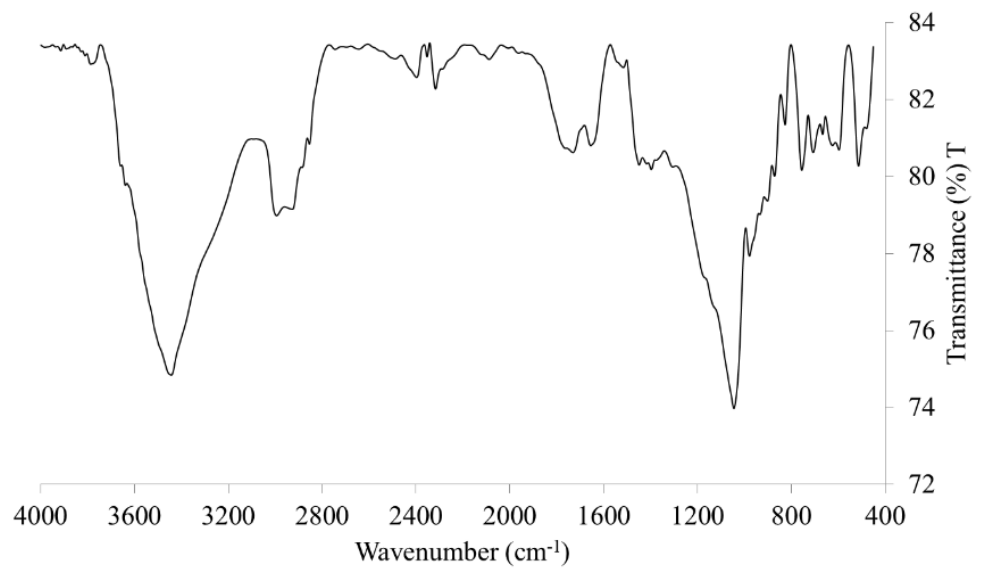

Fig. 1. FTIR spectrum of a PHA sample.

The TGA thermogram (Fig. 2) shows two mass losses: one at $254.98{ }^{\circ} \mathrm{C}$ and another at $325.44{ }^{\circ} \mathrm{C}$, corresponding to the PHA and PLA decomposition reactions, respectively. Additionally, a residue of $2.944 \%$ is observed around $600{ }^{\circ} \mathrm{C}$. Thermogravimetric analysis of PLA reported in the literature show that this polymer degrades at a temperature between 375 ${ }^{\circ} \mathrm{C}$ and $382{ }^{\circ} \mathrm{C}$; however, the presence of PHA in the compound decreases this temperature [14]. Therefore, we associate the mass loss seen at $325.44{ }^{\circ} \mathrm{C}$ with the degradation reactions of PLA. The mass loss observed at $254.98{ }^{\circ} \mathrm{C}$ is associated with the decomposition of PHA, which might correspond to polyhydroxybutyrate (PHB) or polyhydroxybutyric acid that is a type of polyhydroxyalkanoate [14]. Guan [14] reported a degradation temperature for the PLA of approximately $375^{\circ} \mathrm{C}$ for PHB/PLA compounds in a $75 / 25 \mathrm{w} / \mathrm{w}$ ratio, and suggested that the greater amount of PHB present 
in the sample, the lower the degradation temperature experienced by the PLA. Other authors who used PHB and a PHB/PLA ratio of 25/75 reported similar temperatures for the degradation of the PLA: $350{ }^{\circ} \mathrm{C}$ [9] and $355^{\circ} \mathrm{C}$ [12]. Therefore, we can conclude that due to the decrease in the degradation temperature of the PLA, the PHA represents the main polymer in the compound studied. It is possible to determine the relationship of the elements present with the TGA, however, to reduce errors, it is necessary to have a TGA curve for each element separately, so that the percentages of weight loss can be determined due to humidity and other aspects. In this case, we carried out the calculations without these precisions, therefore, the result obtained is an estimate; according to this, the ratio of the material is $1.37: 1$ of PHA/PLA (56.10 / 40.95) [15].

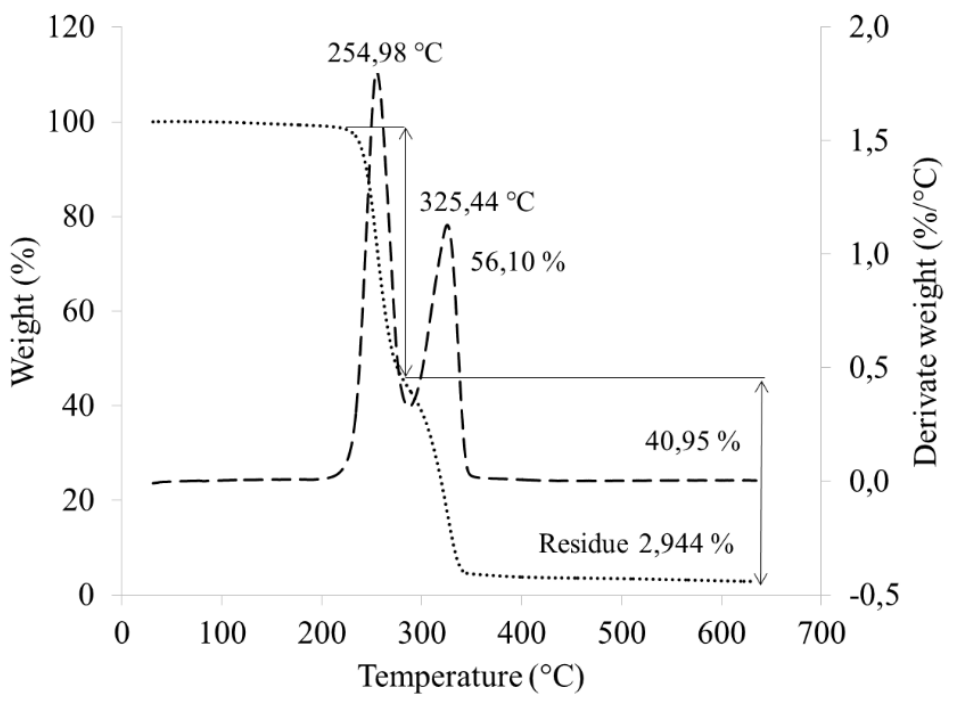

Fig. 2. TGA thermogram of a PHA sample

\section{B. Characterization of the PHA scaffolds}

The study of the morphological constitution of the scaffolds showed interconnected pores allowing cell migration (Fig. 3). Pore size distribution was quantified in both cross and longitudinal sections (Fig. 4a) using the software ImageJ. The lack of a clear trend may suggest that the type of slice did not influence pore formation, however, the protocol 7.5\% PHA showed the greatest difference, with the pores in cross section being approximately 2.3 times larger in diameter than those in longitudinal section. This phenomenon, which was not evident in the other protocols, may be explained by the transversal direction in which cooling was applied during lyophilization, and by the adequate amount of polymer dissolved that allowed the material to adjust according to the cooling direction. 

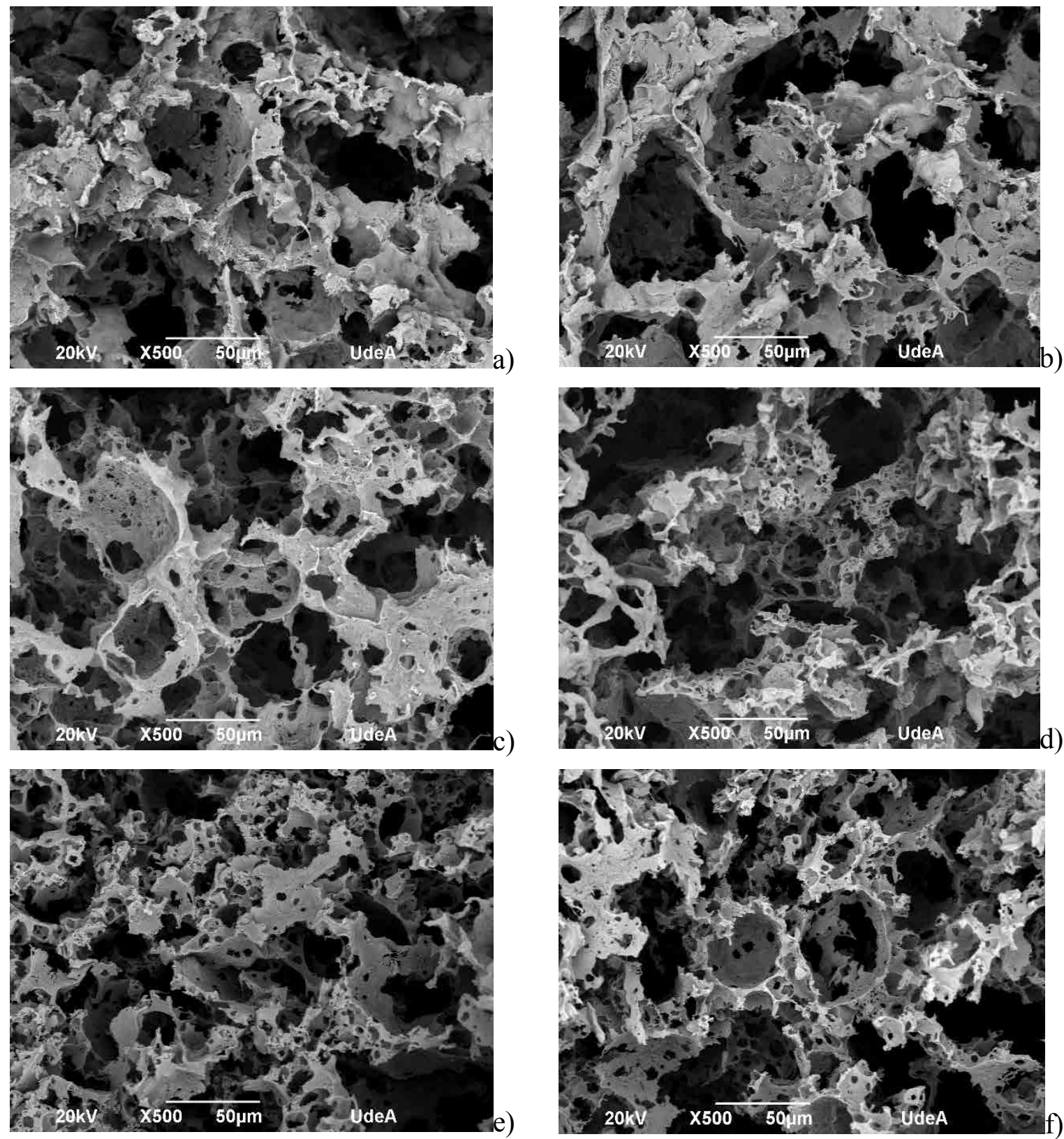

Fig. 3. SEM Micrographs. a) 5\% PHA lateral cut, b) 5\% PHA transversal cut, c) 7.5\% PHA lateral cut, d) 7.5\% PHA transversal cut, e) 10\% PHA lateral cut, f) $10 \%$ PHA transversal cut.

The transverse cuts of $5 \%$ PHA and lateral cuts of $7.5 \%$ PHA showed a greater pore size (approximately 34 $\mu \mathrm{m}$ in diameter) compared to the other protocols (Fig. $3,4 a)$. The lateral cuts of 5\% PHA and the transversal and lateral cuts of $10 \%$ PHA had a greater pore size distribution (34-60 $\mu \mathrm{m}$ in diameter) compared to the previous cuts. Finally, the pore size distribution of the transversal cuts of $7.5 \%$ PHA was the most dispersed, frequently with pores of $80 \mu \mathrm{m}$ in diameter. Figure $4 \mathrm{~b}$ shows the circularity of the pores, which are not significantly different. 


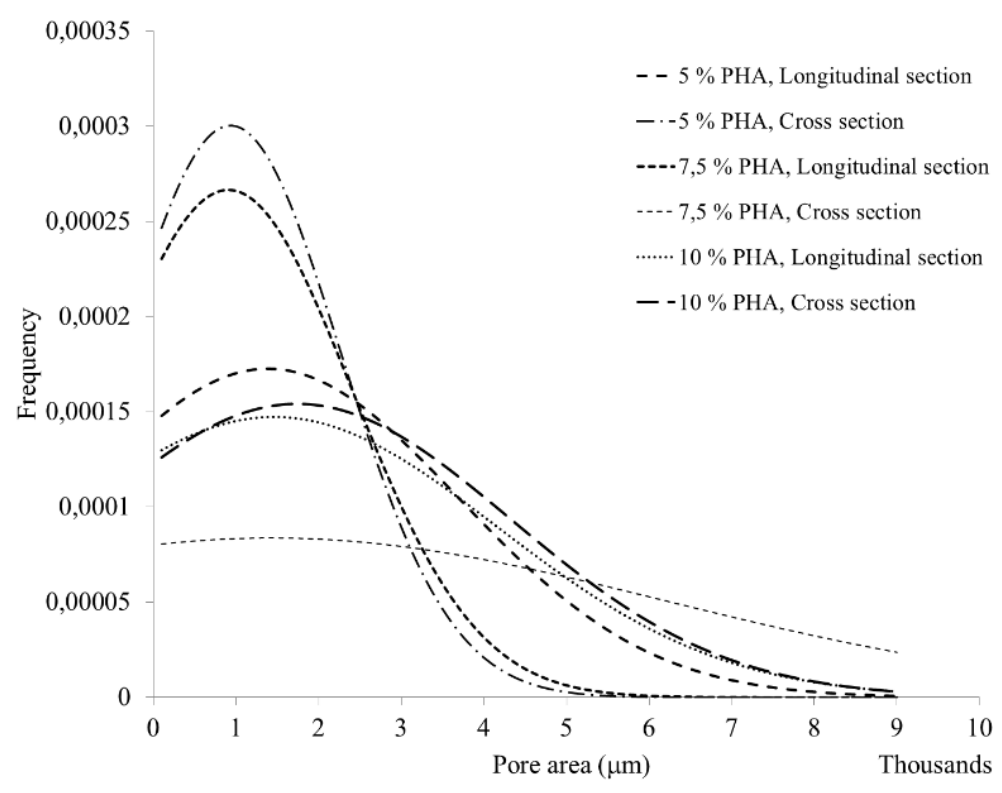

a)

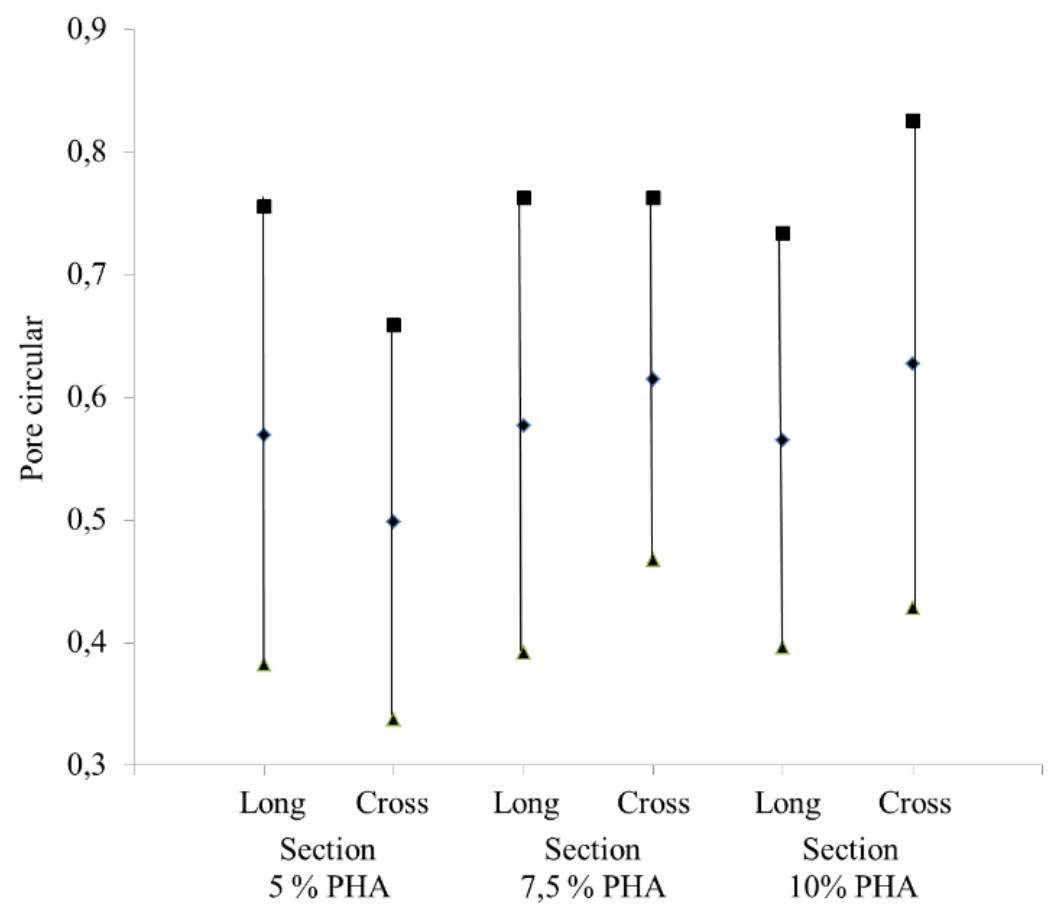

Fig. 4. a) Normal distribution of the pore areas present in the scaffolds, b) Graphical representation of the average and standard deviation of the circularity value of the pores.

Figure 5 shows the direct relationship between the amount of PHA in the sample and the compression strength: the higher the percentage of PHA, the greater the mechanical strength. 


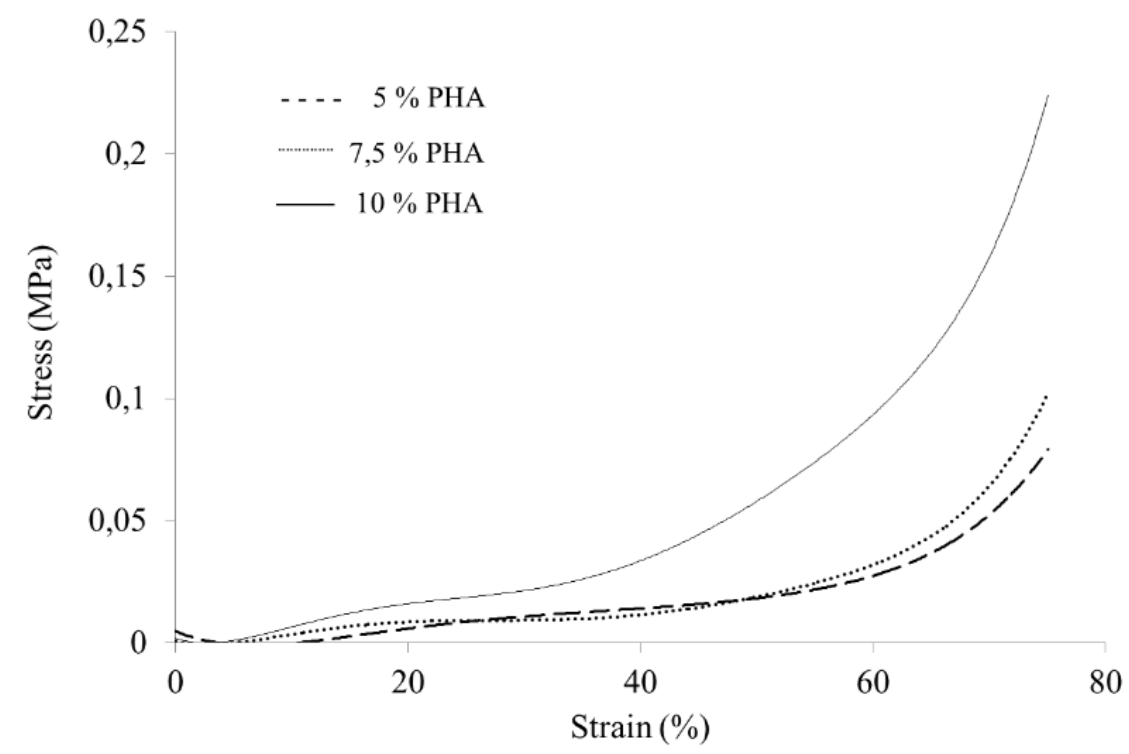

Fig. 5. Smoothed stress-strain curve obtained from the PHA scaffolds compression test.

Fourth generation biomaterials [16] seek to imitate the properties of tissues through morphological similarity; therefore, cartilage substitutes should have materials that can imitate the tissue's properties. In this aspect, the scaffolds obtained lacked the adequate mechanical strength. The tendency curves (Fig. 5) showed a maximum strength of $0.229 \mathrm{MPa}$ at a deformation of $75 \%$, corresponding to the $10 \%$ PHA protocol; this may be due to the greater amount of material that provides greater resistance to compression. However, human articular cartilage resists compression between 1 and $10 \mathrm{MPa}$ at a deformation of $15 \%$ [17]. Nevertheless, several studies propose using biomaterials with mechanical strength lower than that of the host tissue [18], because the mechanical resistance is not only determined by the inorganic material but by the cells and other organic elements such as collagen [17] that reinforce the material, increasing its mechanical resistance. The mechanical behavior of the cartilage starts with a high percentage of deformation at small loads and decreases as the load increases due to the structure reorganization [17]; the scaffold manufactured in this study showed the same behavior. The natural behavior mimicry is a promising sign for using PHA scaffolds as a chondrocyte growth platform.

Figure 6 shows the degradation curves determined through the mass loss for the PHA scaffolds over time. It is evident that the protocol $7.5 \%$ PHA allowed the degradation of the sample up to approximately $50 \%$ in 28 days, unlike the other two protocols: for $10 \%$ PHA, a maximum value was reached around $25 \%$, and for 5\% PHA, which had the lowest percentage and the greatest stability over time, a degradation value of approximately $5 \%$ was reached. 


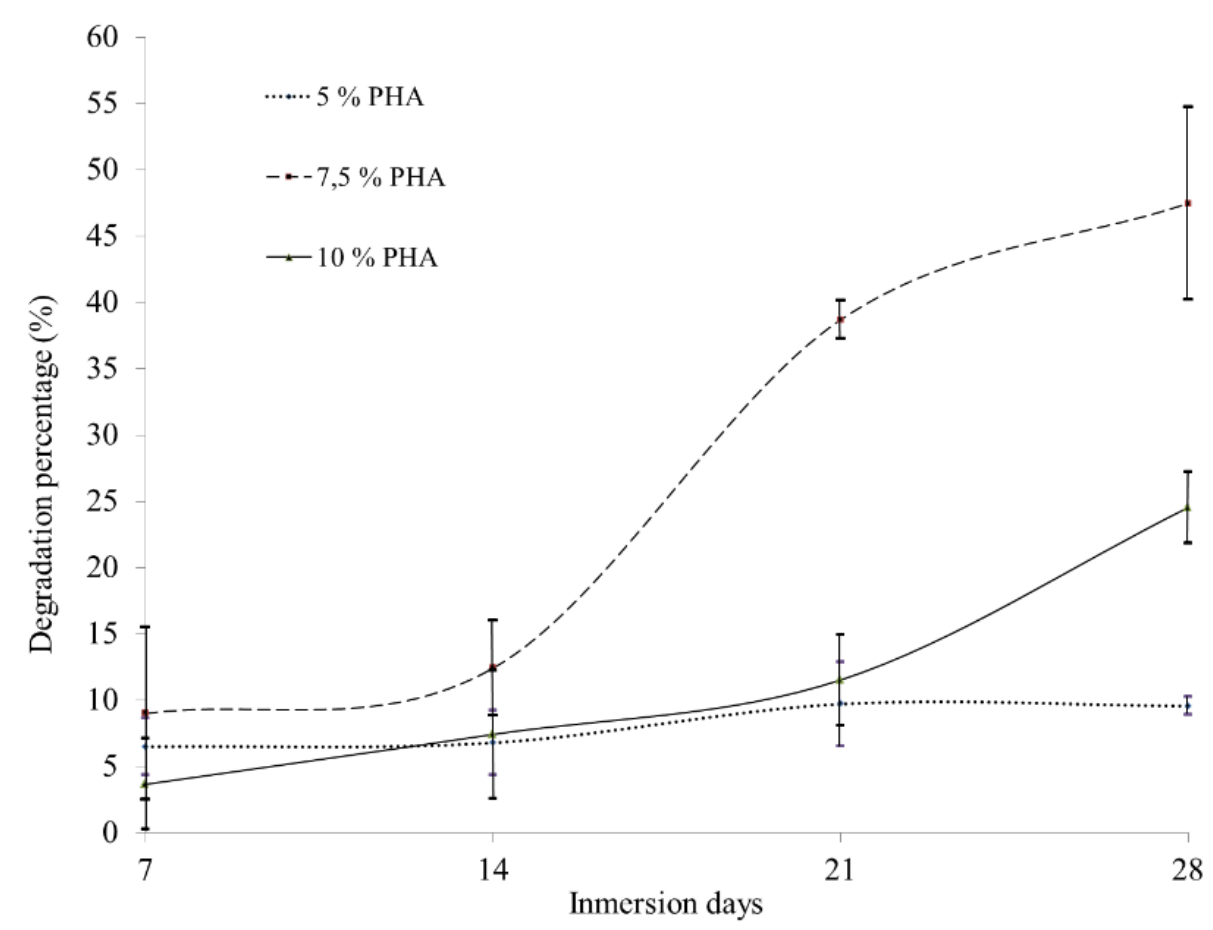

Fig. 6. Graphical representation of the PHA scaffolds mass loss during the degradation test.

The 7.5\% PHA protocol had a higher rate of degradation compared to the other protocols (Fig. 6). This phenomenon can be explained considering the results of the SEM micrographs (Fig. 2), since the morphology of the pores of this protocol is the only one that is determined by the direction of the freezing gradient applied on the precursor solution of the scaffold, therefore, the proportion of $7.5 \%$ of PHA allowed controlling the orientation of the pores, and facilitated the degradation in a simulated body environment. According to Cedeño et al. [19], the growth capacity of chondrocytes after eight weeks of an implanted graft is $50 \%$ to $90 \%$ and depends on the cellular stimulus. Although the test carried out does not contain cells, the SBF solution represents a physiological simulation, which makes possible to compare with the results of this study. The scaffold of $7.5 \%$ PHA was degraded by $50 \%$ after four weeks of exposure, which is very promising, since with the appropriate stimulus an adequate degradation rate can be achieved for the proliferation of chondrocytes in a cartilage implant.

\section{Conclusions}

The scaffolds obtained using different percentages of PHA have adequate porosity characteristics for cell migration, since they have interconnected pores ranging from $34 \mu \mathrm{m}$ to $500 \mu \mathrm{m}$; given that the chondrocytes have sizes between $30 \mu \mathrm{m}$ and $40 \mu \mathrm{m}$, the pore sizes obtained would allow migration inside the scaffold. The scaffolds with $7.5 \%$ PHA showed significant differences between the pore sizes in transversal and longitudinal sections; this may be due to the freezing gradient direction, which could have influenced the scaffolds degradation capacity, with percentages of 50\% compared to the other protocols that lost approximately $10 \%$ and $25 \%$. The mechanical compression strength of all the PHA scaffolds was low compared to that of natural cartilage; however, the mechanical behavior is similar to the articular cartilage, making these scaffolds an excellent option for tissue regeneration.

\section{ACKNOWLedgements}

The authors thank the Biomaterials Research Group (BIOMAT) from the Bioengineering Program at the University of Antioquia for financing the project, and the members of the Research Group for the support in its execution. 


\section{REFERENCES}

[1] Departamento Administrativo Nacional de Estadísticas (DANE), "Información estadística por discapacidad," Total nacional, 2010. [Online]. Available: $\quad$ http://www.dane.gov.co/index.php/ poblacion-y-demografia/discapacidad.

[2] E. C. Chan, "Sustitutos de tejido óseo," Orthotips, vol. 10(4), pp. 208-217, 2014.

[3] N. Zapata, N. Zuluaga, S. Betancur, et al., "Cultivo de tejido cartilaginoso articular: Acercamiento conceptual," Rev. Esc. Ing. Antioquia, vol. 8, pp. 117-129, Dec. 2007.

[4] C. Navarro Hernández et al., "Proyecto multidisciplinario para la fabricación de prótesis ortopédicas de bajo costo," Ideas Concyteg, vol. 6(72), pp. 788-798, 2011.

[5] A. C. Ríos, D. Hotza, G. V Salmoria, et al., "Fabricación de andamios de hidroxiapatita por impresión tridimensional," Rev. Lat. Metal. y Mater., vol. 34(2), pp. 262-274, 2013.

[6] M. You, et al., "Chondrogenic differentiation of human bone marrow mesenchymal stem cells on polyhydroxyalkanoate (PHA) scaffolds coated with PHA granule binding protein $\mathrm{PhaP}$ fused with RGD peptide," Biomaterials, vol. 32(9), pp. 2305-13, Mar. 2011. DOI: https://doi.org/10.1016/j. biomaterials.2010.12.009.

[7] D. Yalçin, T. Baykal, Đ. Açikgöz, et al., "Fourier Transform Infrared (FT-IR) Spectroscopy for Biological Studies. Review." G.U. J. Sci., vol. 22(3), pp. 117-121, 2009.

[8] I. PerkinElmer, "A Beginner's Guide," Thermogravimetric Analysis (TGA), 2015.

[9] M. P. Arrieta, E. Fortunati, F. Dominici, et al., "Multifunctional PLA-PHB/cellulose nanocrystal films: processing, structural and thermal properties.," Carbohydr. Polym., vol. 107, pp. 16-24, Jul. 2014. DOI: https://doi.org/10.1016/j.carbpol.2014.02.044.

[10] Y.-X. Weng, L. Wang, M. Zhang, et al., "Biodegradation behavior of $\mathrm{P}(3 \mathrm{HB}, 4 \mathrm{HB}) / \mathrm{PLA}$ blends in real soil environments," Polym. Test., vol. 32(1), pp. 60-70, Feb. 2013. DOI: https://doi. org/10.1016/j.polymertesting.2012.09.014.
[11] S. V.Naveen, I. K. P.Tan, Y.S. Goh, et al., "Unmodified medium chain length polyhydroxyalkanoate (UMCLPHA) as a thin film for tissue engineering application - characterization and in vitro biocompatibility," Mater. Lett., vol. 141, pp. 55-58, Feb. 2015. DOI: https://doi.org/10.1016/j.matlet.2014.10.144.

[12] M. P. Arrieta, E. Fortunati, F. Dominici, et al., "Bionanocomposite films based on plasticized PLAPHB/cellulose nanocrystal blends," Carbohydr. Polym., vol. 121, pp. 265-75, May. 2015. DOI: https://doi.org/10.1016/j.carbpol.2014.12.056.

[13] M. P. Arrieta, J. López, A. Hernández, et al., "Ternary PLA-PHB-Limonene blends intended for biodegradable food packaging applications," Eur. Polym. J., vol. 50, pp. 255-270, Jan. 2014. DOI: https://doi.org/10.1016/j.eurpolymj.2013.11.009.

[14] Q. Guan, "Fabrication and Characterization of PLA, PHBV and Chitin Nanowhisker Blends, Composites and Foams for High Strength Structural Applications," Master Thesis, Mechanical Engineering, University of Toronto, 2013.

[15] G. Widmann, "Informaciones para los usuarios de los sistemas de termoanálisis METTLER TOLEDO," UserCom, pp. 1-20, 2001

[16] C. Ning, L. Zhou, and G. Tan. "Fourth-generation biomedical materials," Mater. Today, vol. 19 (19, pp. 2-3, Jan. 2016. DOI: https://doi.org/10.1016/j. mattod.2015.11.005.

[17] C. M. Hernández, "Estudio mecánico, histológico e histomorfométrico del regenerado de cartílago a partir de injertos de periosto invertido," Doctoral Thesis, Universidad Autónoma de Barcelona, 2015.

[18] J. J. Pavón Palacio, A. Pesquet, M. Echeverry Rendón, et al., "Procesamiento, caracterización y ensayos biológicos de scaffolds poliméricos naturales y sintéticos para ingeniería de tejido óseo y cartilaginoso," Rev. Politécnica, vol. 10 (19), pp. 9-19, 2014.

[19] N. E. Cedeño Lamus, J. L. Acosta Collado, and N. Antoniadis Petrakis, "Análisis histológico de los injertos de cartílago autólogos envueltos en fascia," Cirugía Plástica Ibero-Latinoamericana, vol. 37(2), pp. 111-121, 2011. 